\title{
'Vernon' Rabbiteye Blueberry
}

\author{
D. Scott NeSmith ${ }^{1}$ \\ Department of Horticulture, Georgia Station, Griffin, GA 30223-1797
}

\section{Arlen D. Draper ${ }^{2}$ and James M. Spiers ${ }^{3}$ \\ U.S. Department of Agriculture, Agricultural Research Service, Small Fruit Laboratory, Poplarville, MS 39470}

Additional index words. Vaccinium ashei, fruit breeding, cultivar, ripening date

'Vernon' is a new rabbiteye blueberry ( $\mathrm{Vac}$ cinium ashei Reade) jointly released by The University of Georgia College of Agricultural and Environmental Sciences, The University of Georgia Agricultural Experiment Station, and the U.S. Department of Agriculture's Agricultural Research Service(USDA-ARS). 'Vernon' is an early ripening rabbiteye blueberry, having favorable fruit attributes, large berry size, good yields, and excellent plant vigor, when compared to the early ripening cultivars 'Climax' and 'Premier' (Brightwell and Draper, 1975; Krewer and NeSmith, 2000). Plants of 'Vernon' flower relatively late ( 7 to $10 \mathrm{~d}$ after 'Climax' in southern Georgia), yet ripen early (same time as 'Climax'). Berries of 'Vernon' are large and have excellent firmness, color, flavor and dry scars that contribute to good shelf life.

\section{Origin}

'Vernon' was selected in 1990 at the Coastal Plain Experiment Station in Tifton, Ga., from a cross of T-23 X T-260 and was tested as selection T-584. A pedigree of 'Vernon' is depicted in Fig. 1. The selection was tested in a planting at the University of Georgia's Blueberry Research Farm near Alapaha, Ga., beginning in 1995. In 2001, 'Vernon' was entered in the Southern Regional Blueberry Evaluation Trial, where it was tested at diverse locations including Alapaha, Georgia; Clarksville, Ark., (location of the University of Arkansas' Fruit Substation Research Farm); and Poplarville, Miss. (location of the USDA-ARS Small Fruit Laboratory). Data from several site/years indicate that 'Vernon' performed well across the southern U.S. in areas where rabbiteye blueberries are grown.

\section{Description and Performance}

The rabbiteye blueberry is the major commercially grown blueberry species in many areas of the southeastern U.S. Early ripening rabbiteye cultivars are few, with 'Climax' and 'Premier' being the current industry standards.

Received for publication 25 Aug. 2005. Accepted for publication 8 Sept. 2005. A contribution of the University of Georgia Agricultural Experiment Station, Georgia Station, Griffin, and USDA-ARS, Poplarville, Miss. This research was supported, in part, by state and Hatch Act funds allocated to the Georgia Agricultural Experiment Stations.

${ }^{1}$ Professor.

${ }^{2}$ Research geneticist, retired.

${ }^{3}$ Research horticulturist.
In Georgia, 'Climax' yields have been highly unreliable, and 'Premier' yields have been only moderate. Also, 'Climax' is subject to spring freeze damage due to early blooming. Table 1 depicts yields averaged across five years at Alapaha, Georgia for 'Vernon', 'Climax', and 'Premier'. 'Vernon' yielded $87 \%$ more than 'Climax' overall, and there was a trend for a yield increase compared to 'Premier'. Table 2 portrays average yields for 'Vernon' and 'Climax' (plants established in a replicated test in 2001) at Griffin and Blairsville, Georgia averaged over 2003 and 2004. 'Vernon' and 'Climax' yields were similar in Griffin; however 'Vernon' yielded more than 'Climax' in Blairsville. Yields at all locations were taken from three single plant replicates for each cultivar and statistical analyses were conducted across years.

Flowering and ripening times are important data for growers considering production of rabbiteye blueberries. Generally, early flowering times predispose plants to frost damage, and

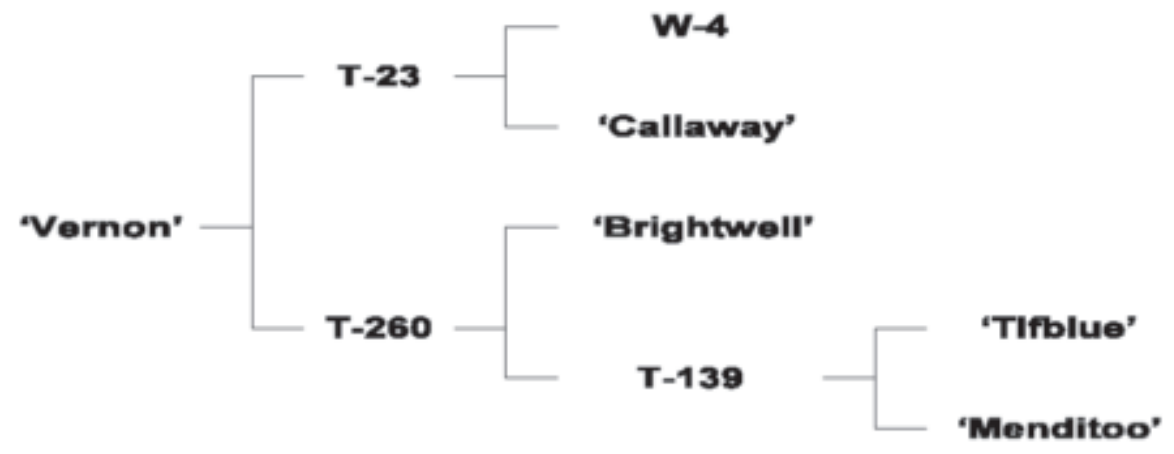

Fig. 1. Pedigree of 'Vernon' rabbiteye blueberry.

Table 1. Yields, flowering and ripening dates, and ratings of berry and plant attributes of 'Vernon', 'Climax', and 'Premier' rabbiteye blueberries at Alapaha, Georgia. Data are averages for a 5-year period (1999-2003). Yields (kg/plant) were taken from three single plant replicates for each cultivar and berry weight $(\mathrm{g})$ was determined at first harvest from multiple 50- to 100-berry samples. Dates are estimates of $50 \%$ flowering and ripening times. Other ratings are on a scale of $1=$ poorest to 10 $=$ best, with a value of 6 to 7 generally considered commercially acceptable. Plants of each blueberry clone were established in 1992.

\begin{tabular}{lccc}
\hline & \multicolumn{3}{c}{ Berry/plant } \\
\cline { 2 - 4 } Attribute & \multicolumn{3}{c}{ Cultivar } \\
\cline { 2 - 4 } Yield (kg/plant) & Vernon & Climax & Premier \\
Flowering date & $5.8 \mathrm{a}^{\mathrm{z}}$ & $3.1 \mathrm{~b}$ & $4.5 \mathrm{ab}$ \\
Ripening date & 17 Mar. c & 7 Mar. a & Mar. b \\
Berry wt. (g) & 31 May a & 30 May a & 2 June a \\
Berry scar & $1.87 \mathrm{a}$ & $1.27 \mathrm{~b}$ & $8.0 \mathrm{a}$ \\
Berry color & $8.8 \mathrm{a}$ & $8.2 \mathrm{a}$ & $8.0 \mathrm{a}$ \\
Berry firmness & $8.5 \mathrm{a}$ & $8.1 \mathrm{a}$ & $7.4 \mathrm{~b}$ \\
Berry flavor & $8.5 \mathrm{a}$ & $8.3 \mathrm{a}$ & $8.3 \mathrm{a}$ \\
Plant vigor & $7.5 \mathrm{a}$ & $8.0 \mathrm{a}$ & $8.8 \mathrm{a}$ \\
\hline
\end{tabular}


Table 2. Yield of the rabbiteye blueberry 'Vernon' and the standard cultivar 'Climax' averaged over 2003 and 2004 at Griffin and Blairsville, Ga. Plants were established in 2001, and were grown with pine bark mulch and irrigation. Yields were taken from three single plant replications per cultivar each year.

\begin{tabular}{llc}
\hline & \multicolumn{2}{c}{ Total yield per bush $(\mathrm{kg})$} \\
\cline { 2 - 3 } Location & \multicolumn{2}{c}{ Cultivar } \\
\cline { 2 - 3 } & Vernon & Climax \\
\hline Griffin & $3.3 \mathrm{a}^{\mathrm{z}}$ & $2.8 \mathrm{a}$ \\
Blairsville & $4.9 \mathrm{a}$ & $1.7 \mathrm{~b}$ \\
\hline
\end{tabular}

${ }^{z}$ The same lower case letter indicates means in a row were not significantly different at $p \leq 0.05$.

2003. The two cultivars generally ripened at the same time, and were similar with respect to berry scar, color, firmness, and flavor (data not shown). 'Vernon' had larger berry size than 'Climax' across these locations, and typically had better plant vigor also (data not shown). Crop load of 'Vernon' was greater than 'Climax' at two of the locations. Addi- tional observations on farms in Baxley, Ga.; Waycross, Ga.; and White Lake, N.C., during 2004 indicated that 'Vernon' was performing well at those locations.

'Vernon' appears to be as self-fertile as 'Brightwell' (NeSmith, 1999). However, it is recommended that 'Vernon' be planted with another rabbiteye cultivar similar in bloom date to facilitate cross pollination. The recent release 'Alapaha' (NeSmith et al., 2002) should be suitable for planting with 'Vernon', as should the cultivars Austin (Hall and Draper, 1997) and Premier. 'Climax' may be a less suitable choice for cross pollination in southern Georgia, since its bloom date is usually earlier.

\section{Availability}

'Vernon' is a patent pending cultivar owned by the University of Georgia Research Foundation. Contact the Georgia Seed Development Commission, 2420 S. Milledge Ave., Athens, GA 30606 (www.gsdc.com) for information on plant source and availability. Neither the Georgia Agricultural Experiment Station nor the USDA-ARS have plants for sale or distribution.

\section{Literature Cited}

Brightwell, W.T. and A.D. Draper. 1975. The 'Bluebelle' and 'Climax' rabbiteye blueberries. Fruit Var. J. 29:44.

Hall, M.R. and A.D. Draper. 1997. 'Austin' rabbiteye blueberry. HortScience 32:1295-1296.

Krewer, G. and D.S. NeSmith. 2000. Blueberry cultivars for Georgia. http://www.smallfruits. org/Blueberries/production/BlueberryCultiv. htm.

NeSmith, D.S. 1999. Response of 'Brightwell' rabbiteye blueberry to self and cross pollination. A 1999 research report, p. 30-32. In: D.S. NeSmith (ed.). Blueberry research at the University of Georgia. Univ. Ga. College of Agr. Environ. Sci., Athens, Res. Rpt. 662.

NeSmith, D.S., A.D. Draper, and J.M. Spiers. 2002. 'Alapaha' rabbiteye blueberry. HortScience 37:714-715. 